\title{
Effect of oral terfenadine on the bronchoconstrictor response to inhaled histamine and adenosine 5 '-monophosphate in non-atopic asthma
}

\author{
GERRARD D PHILLIPS, PAUL RAFFERTY, RICHARD BEASLEY, \\ STEPHEN T HOLGATE
}

From Medicine I, Southampton General Hospital, Southampton

\begin{abstract}
Inhaled adenosine 5'-monophosphate (AMP) causes bronchoconstriction in atopic asthma, probably after in vivo conversion to adenosine. It has been suggested that adenosine potentiates preformed mediator release from mast cells on the mucosal surface of the airways by interacting with specific purinoceptors, without affecting the release of newly generated mediators. The airway response of nine non-atopic subjects with "intrinsic" asthma to inhaled AMP and the influence of the oral, selective $\mathrm{H}_{1}$ histamine receptor antagonist terfenadine on this response was investigated. The geometric mean provocation concentrations of histamine and AMP required to produce a $20 \%$ fall in $\mathrm{FEV}_{1}\left(\mathrm{PC}_{20}\right)$ were 1.82 and $13 \mathrm{mmol} / \mathrm{l}$. In subsequent placebo controlled time course studies the $\mathrm{FEV}_{1}$ response to a single inhalation of the $\mathrm{PC}_{20}$ histamine was ablated after pretreatment with oral terfenadine $180 \mathrm{mg}$. This dose of terfenadine caused an $80 \%$ inhibition of the bronchoconstrictor response to the $\mathrm{PC}_{20} \mathrm{AMP}$ when measured as the area under the time courseresponse curve and compared with the response to $\mathrm{PC}_{20} \mathrm{AMP}$ preceded by placebo. Terfenadine 600 $\mathrm{mg}$ failed to increase protection against AMP further, but both doses of terfenadine delayed the time at which the mean maximum fall in $\mathrm{FEV}_{1}$ after AMP was achieved. Terfenadine $180 \mathrm{mg}$ had no effect on methacholine induced bronchoconstriction in the same subjects. These data suggest that inhaled AMP may potentiate the release of preformed mediators from preactivated mast cells in the bronchial mucosa of patients with intrinsic asthma.
\end{abstract}

\section{Introduction}

Adenosine is a naturally occurring purine nucleoside formed from the cleavage of adenosine 5 '-monophosphate (AMP) by $5^{\prime}$-nucleotidase.' Its physiological effects are due to stimulation of cell surface purinoceptors associated with adenylate cyclase, to cause either a decrease $\left(A_{1}\right)$ or an increase $\left(A_{2}\right)$ in intracellular levels of cyclic $3^{\prime} 5^{\prime}$-AMP. ${ }^{2}$ When inhaled by atopic subjects with asthma adenosine causes concentration related bronchoconstriction, which reaches maximum 3-5 minutes after challenge and gradually subsides over $30-60$ minutes. ${ }^{3}$ We have recently reported that the adenosine nucleotide AMP

Address for reprint requests: Dr G Phillips, Medicine I, Level D, Centre Block, Southampton General Hospital, Southampton SO9 4XY.

Accepted 14 July 1987 also provokes bronchoconstriction in subjects with allergic asthma, probably after in vivo conversion to adenosine. ${ }^{4}$ The response of asthmatic airways to adenosine is selectively antagonised by the competitive adenosine receptor antagonist theophylline, ${ }^{56}$ and potentiated by the adenosine uptake inhibitor dipyridamole, ${ }^{7}$ suggesting that it is likely to be occurring through stimulation of specific cell surface purinoceptors.

Recent work suggests that the bronchoconstrictor effect of adenosine depends on the release of spasmogenic mediators from activated bronchial mast cells. $^{8-10}$ Thus adenosine and synthetic analogues with some specificity for $A_{2}$ purinoceptors potentiate mediator release from preactivated rodent ${ }^{11}$ and human $^{8}$ mast cells, although this effect appears to be restricted to the release of preformed and not newly generated mediators. ${ }^{11}$

Within the secretory granules of human mast cells histamine is the only preformed mediator known to 
contract airway smooth muscle. In subjects with atopic asthma the potent and selective $\mathrm{H}_{1}$ histamine receptor antagonists terfenadine and astemizole almost completely inhibit the bronchoconstrictor response to inhaled AMP, while reducing the immediate allergen induced response by only $50 \% .^{12}$ Thus in asthma associated with atopy the airways response to AMP probably results from the augmentation of histamine release from activated mast cells on the surface of the bronchial mucosa.

In 1947 Rackemann introduced the term intrinsic asthma to describe asthmatic patients in whom a causative external allergen could not be implicated. ${ }^{13}$ The role of inflammatory cells and their mediators in the pathogenesis of intrinsic asthma, however, has been little investigated. In this study we have investigated the airways response of patients with intrinsic asthma to inhaled AMP and the influence of $H_{1}$ histamine receptor blockade with the $H_{1}$ antihistamine terfenadine on this response.

\section{Methods}

\section{SUBJECTS}

Nine patients, seven of them women, with a mean age of 56 (SEM 5) years, participated in the study. All subjects were non-smokers with intrinsic (non-atopic) asthma as defined by negative responses to prick skin tests ( $<2 \mathrm{~mm}$ weal response) with 10 common allergens (house dust, Dermatophagoides pteronyssinus, Dermatophagoides farinae, mixed grass pollen, tree pollen, cat fur, dog hair, feathers, Candida albicans, and Aspergillus fumigatus-Bencard, Brentford, Middlesex), no history of occupational asthma or diseases associated with atopy, and serum IgE concentrations within the normal range $(<81 \mathrm{IU} / \mathrm{ml})$. An eosinophil count was performed on a venous blood sample. All patients had a baseline forced expiratoly volume in one second $\left(\mathrm{FEV}_{1}\right)$ of over $60 \%$ of predicted values or $>1.51$, and none was receiving oral cortichsteroids, theophylline, or sodium cromoglycate on regular basis (table 1). Bronchodilators were net inhaled for eight hours before each visit to the laboratory, although patients were allowed to continue inhaling steroids as usual. No one was studiegd within four weeks of an upper respiratory traet infection or exacerbation of their asthma. Subjects gave informed consent and the study was approved the Southampton University and hospitals ethical committee.

\section{BRONCHIAL PROVOCATION}

Airway calibre was measured before and during the provocation as the better of two consecutive FEW measurements by means of a dry wedge spiromet $\mathrm{g}$ (Vitalograph, Buckinghamshire). On each challenge day histamine acid phosphate (BDH Chemicas, Poole), AMP (Sigma Chemical Co, St Louis, USA), and methacholine (Sigma, Poole, Dorset) were mase up in $0.9 \%$ sodium chloride to produce a range of doubling concentrations of $0.03-8 \mathrm{mg} / \mathrm{ml}(0 \cdot 1-26$ $\mathrm{mmol} / \mathrm{l}), 0.04-100 \mathrm{mg} / \mathrm{ml}(1 \cdot 11-287.9 \mathrm{mmol} / \mathrm{l})$, and $0.03-16 \mathrm{mg} / \mathrm{ml}(0.16-81.74 \mathrm{mmol} / \mathrm{l})$. The solutio were administ red as aerosols generated from a stafi ing volume of $3 \mathrm{ml}$ in a disposable Inspiron mi $\mathrm{i}$ nebuliser (CR Bard International, Sunderland) driven by compressed air at $81 / \mathrm{min}^{-1}$ In these conditions the nebuliser generates an aerosol with a mass median particle diameter of $4.7 \mu \mathrm{m} .{ }^{14}$ Subjects inhaled the aerosolised solutions in five breaths from end tidai volume to full inspiratory capacity via a mouthpiece $\bar{D}^{-5}$

STUDY DESIGN

The study was divided into four phases.

Table 1 Patients' characteristics

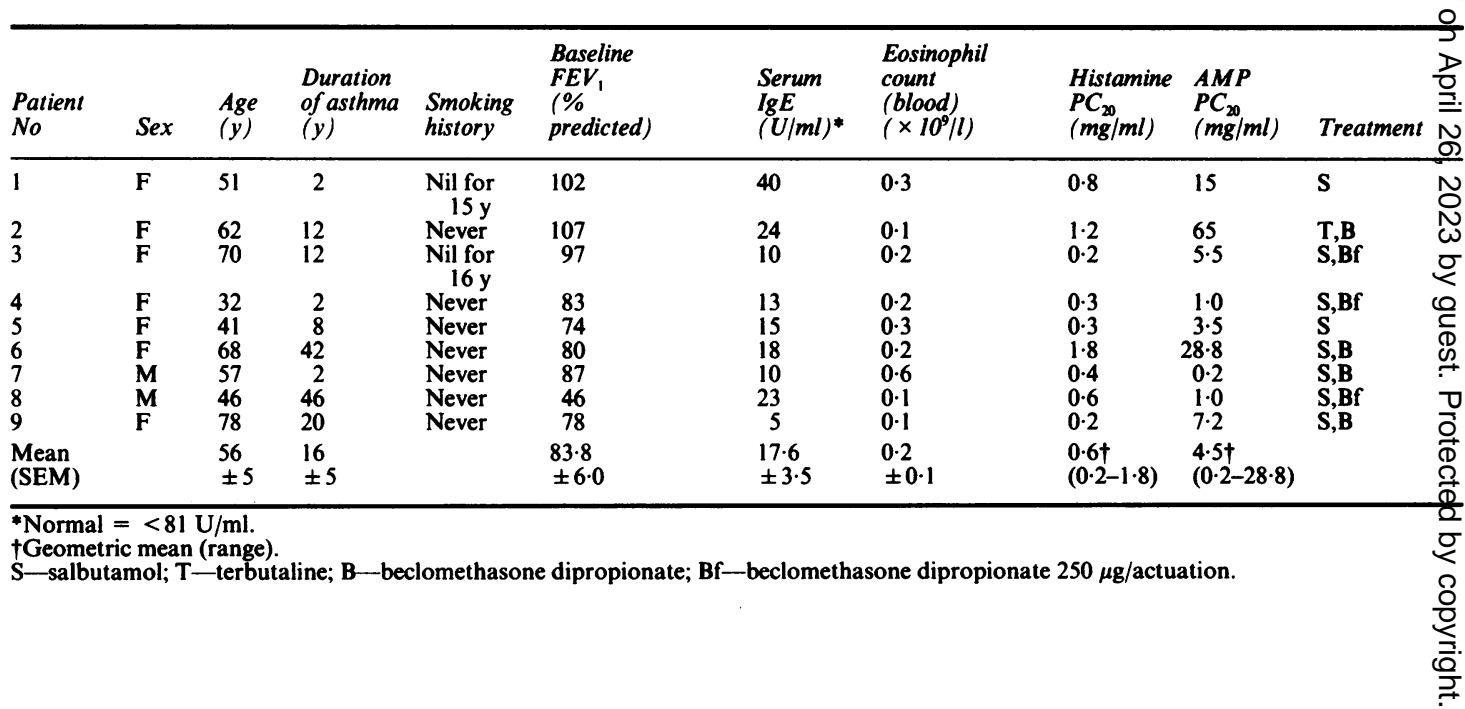




\section{Study 1}

Subjects attended the laboratory at the same time of day on two separate occasions, at least 48 hours apart, to undergo concentration-response studies with inhaled histamine and AMP.

On day 1, after 15 minutes' rest, three baseline measurements of $\mathrm{FEV}_{1}$ were made at three minute intervals. The subjects then inhaled nebulised $0.9 \%$ sodium chloride and the $F E V_{1}$ was measured at 1 and 3 minutes, the higher value being recorded. Provided that the FEV did not fall by more than $10 \%$ of the baseline value, a histamine concentration-response study was carried out. After administration of each histamine concentration FEV, was measured at 1 and 3 minutes and the higher value recorded. Increasing concentrations of histamine were inhaled at five minute intervals until the $\mathrm{FEV}_{\mathrm{l}}$ had fallen by over $20 \%$ of the postsaline baseline value or the highest concentration had been administered. The percentage decrease in FEV, was plotted against the cumulative concentration of histamine administered on a logarithmic scale and the provocation concentration of histamine required to produce a $20 \%$ fall in $\mathrm{FEV}_{\text {, }}$ from the postsaline $\mathrm{FEV}_{1}\left(\mathrm{PC}_{20}\right.$ histamine) derived by linear interpolation. On day 2 a bronchial provocation test with AMP was undertaken in a similar manner and the $\mathrm{PC}_{20}$ value for AMP obtained.

\section{Study 2}

Patients attended the laboratory at the same time of day on four occasions, at least 48 hours apart, to undertake time course studies with inhaled histamine and AMP. These were carried out three hours after they had received oral terfenadine $180 \mathrm{mg}$ or matched placebo, randomised separately for each of the two agonists and administered double blind. On each occasion three baseline measurements of $\mathrm{FEV}_{1}$ were made at three minute intervals after 15 minutes' rest. Nebulised $0.9 \%$ sodium chloride was then administered and repeat $\mathrm{FEV}_{1}$ measurements were made at 1 and 3 minutes. If the $\mathrm{FEV}_{1}$ did not fall by more than $10 \%$ of the baseline value, the previously determined $\mathrm{PC}_{20}$ histamine or AMP was administered and measurements of $\mathrm{FEV}_{1}$ were recorded at regular intervals up to 45 minutes after the challenge. On the two occasions when inhaled histamine was given after oral placebo and terfenadine, a concentration-response study was performed with increasing doubling concentrations of histamine acid phosphate administered by skinprick, the doses ranging from 4 to $128 \mathrm{mg} /$ $\mathrm{ml}(13-416 \mathrm{mmol} / \mathrm{l})$. The total weal circumference at 10 minutes with each concentration of histamine was measured by computer assisted planimetry and integrated to obtain weal area. ${ }^{16}$

Study 3

The $\mathrm{PC}_{20}$ AMP was administered three hours after subjects had received a higher dose of terfenadine $(600$ $\mathrm{mg}$ ) and the changes in $\mathrm{FEV}_{1}$ were again followed for 45 minutes as described above.

Study 4

Patients attended the laboratory on two further occasions at the same time of day one week apart, to perform a concentration-response study with methacholine, three hours after they had received oral terfenadine $180 \mathrm{mg}$ or matched placebo, randomised and administered double blind.

\section{DATA ANALYSIS}

Values are means with standard errors in parentheses unless otherwise stated and $p<0.05$ is accepted as

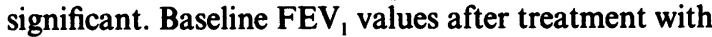
terfenadine were compared with those after placebo by means of Student's $t$ test for paired data. FEV at each $_{1}$ agonist concentration and time interval was expressed as a percentage of the postsaline value. Since postsaline $F E V_{1}$ values after terfenadine were significantly higher than those after placebo, the agonist constrictor response was expressed as a percentage of the postdrug baseline. ${ }^{17}$ The slopes of the histamine and AMP concentration-response curves were determined by least squares linear regression analysis and compared by Student's $t$ test to determine whether the curves departed significantly from parallel. In the time course studies the following three indices were selected to characterise the percentage fall in $\mathrm{FEV}_{1}$-time curves: maximum fall in $\mathrm{FEV}_{1}$, rate of fall in $\mathrm{FEV}_{1}$ to maximum, and the overall bronchoconstrictor response determined by integrating the area under the curve (AUC) by trapezoid integration. The inhibition of bronchoconstriction achieved by terfenadine was determined by subtracting the area of the $\mathrm{FEV}_{1}$-time course curve after active treatment from that after placebo, and expressing the result as a percentage of the placebo response. The measurements obtained from the time course study were compared by two factor analysis of variance and the Newman-Keuls procedure. The total skin weal areas with histamine for each concentration on terfenadine and on placebo days were compared by Student's $t$ test for paired data. The concentration-response curves with methacholine on the different treatment days, expressed as the $\mathrm{PC}_{20}$ values, were compared by means of Student's $t$ test for paired data.

\section{Results}

There were no significant differences in baseline or postsaline $F E V_{1}$ values on any of the study days.

\section{Study 1}

The concentration of inhaled histamine required to produce a $20 \%$ fall in $\mathrm{FEV}_{1}$ from the postsaline baseline ( $\mathrm{PC}_{20}$ histamine) ranged from 0.2 to $1.8 \mathrm{mg} / \mathrm{ml}$ $(0.7-6.0 \mathrm{mmol} / \mathrm{l})$, with a geometric mean of $0.6 \mathrm{mg} / \mathrm{ml}$ 
Table 2 Slopes of agonist concentration-response curves

\begin{tabular}{|c|c|c|c|c|}
\hline \multirow{2}{*}{$\begin{array}{l}\text { Subject } \\
\text { No }\end{array}$} & \multicolumn{2}{|c|}{ Histamine } & \multicolumn{2}{|l|}{$A M P$} \\
\hline & Slope & $r$ & Slope & $r$ \\
\hline $\begin{array}{l}1 \\
2 \\
3 \\
4 \\
5 \\
6 \\
7 \\
8 \\
9\end{array}$ & $\begin{array}{r}-21.6 \\
-8.5 \\
-17.7 \\
-19.3 \\
-12.0 \\
-19.8 \\
-15.7 \\
-8.8 \\
-28.6\end{array}$ & $\begin{array}{l}-0.97 \\
-0.81 \\
-0.89 \\
-0.85 \\
-0.93 \\
-0.98 \\
-0.78 \\
-0.72 \\
-0.99\end{array}$ & $\begin{array}{r}-23.9 \\
-8.8 \\
-30.1 \\
-10.3 \\
-5.5 \\
-9.6 \\
-39.9 \\
-8.7 \\
-14.3\end{array}$ & $\begin{array}{l}-0.92 \\
-0.81 \\
-0.99 \\
-0.97 \\
-0.26 \\
-0.98 \\
-0.74 \\
-0.78 \\
-0.80\end{array}$ \\
\hline $\begin{array}{l}\text { Mean } \\
\text { (SEM) }\end{array}$ & $\begin{array}{l}-16.8 \\
(2 \cdot 2)\end{array}$ & $\begin{array}{l}-0.88 \\
(0.03)\end{array}$ & $\begin{array}{l}-16.5 \\
(3.2)\end{array}$ & $\begin{array}{c}-0.81 \\
(0.07)\end{array}$ \\
\hline
\end{tabular}

$(1.8 \mathrm{mmol} / \mathrm{l})$ table 1 . The $\mathrm{PC}_{20} \mathrm{AMP}$ ranged from 0.2 to $28.8 \mathrm{mg} / \mathrm{ml}(0.6-83 \mathrm{mmol} / \mathrm{l})$ with a geometric mean of $4.5 \mathrm{mg} / \mathrm{ml}(13 \mathrm{mmol} / \mathrm{l})$. There was no significant difference in the slopes of the concentration-response curves with histamine and AMP, mean values being $-16.8(2.2)$ and $-16.5(3.2)$ respectively $(p=0.94$; table 2). Thus, when expressed in molar terms, AMP was $8.4(0.4-46)$ times less potent than histamine in causing bronchoconstriction in this group of subjects. Study 2

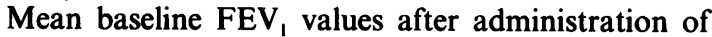
terfenadine $180 \mathrm{mg}(2.2$ and 2.31 on the two study days) were significantly greater than the values obtained after placebo $(2.1$ lon both days; $p<0.02$ table 3). The mean FEV after terfenadine $600 \mathrm{mg}$ $(2.31)$ was not significantly greater than that obtained after terfenadine $180 \mathrm{mg}$.

Administration of the $\mathrm{PC}_{20}$ histamine after placebo caused a rapid fall in $\mathrm{FEV}_{1}$ in all subjects reaching a mean maximum of $69.7 \%(4.4 \%)$ of the postsaline $\mathrm{FEV}_{1}$ at $3.7(0.3)$ minutes. The $\mathrm{FEV}_{1}$ then gradually recovered, although 45 minutes after the challenge it was still significantly below baseline $(10.9 \%(2.9 \%)$; $\mathrm{p}<0.01$ ). After terfenadine $180 \mathrm{mg}$ the $\mathrm{FEV}_{1}$ response to challenge with the $\mathrm{PC}_{20}$ histamine was

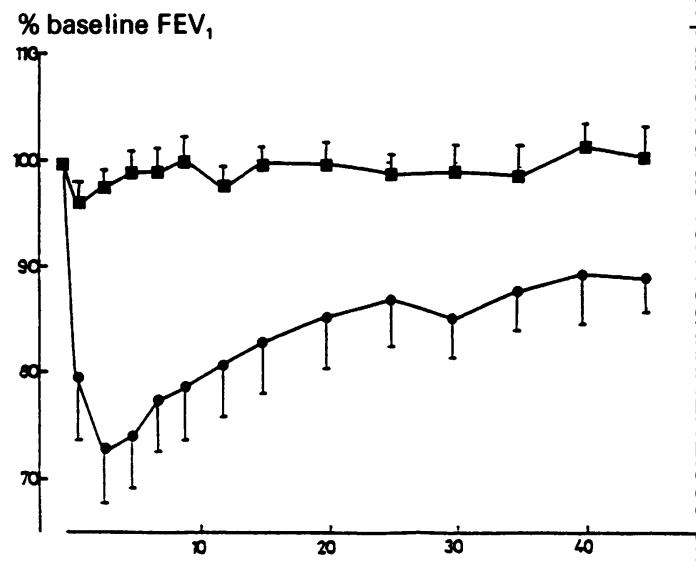

(a)

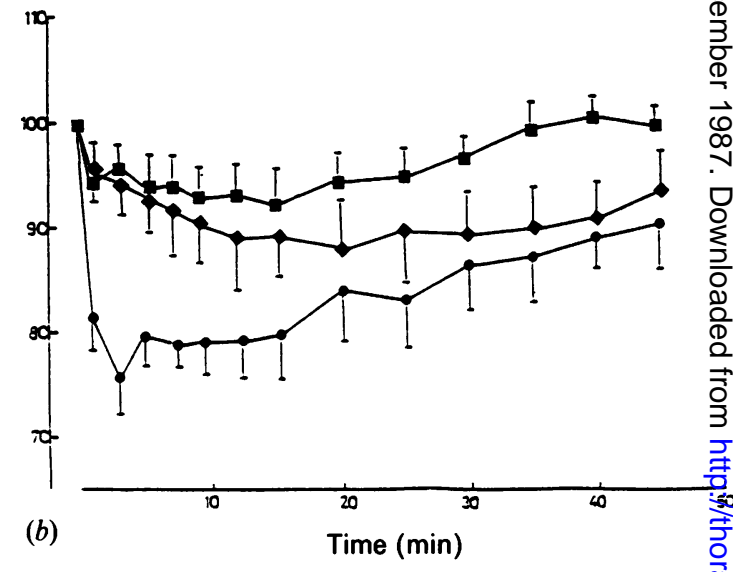

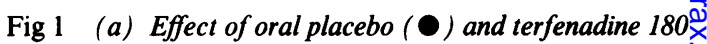

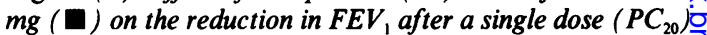
of inhaled histamine. (b) Effect of oral placebo (๑), terfenadine $180 \mathrm{mg}(\mathbf{\square})$, and terfenadine $600 \mathrm{mg}(\bullet)$ on th reduction in $F E V_{1}$ produced by a single dose $\left(P C_{20}\right)$ of inhaled AMP. Each point represents the mean and SEM for ${ }_{\mathrm{O}}$ nine subjects.

Table 3 Baseline $F E V$, values (l)

\begin{tabular}{|c|c|c|c|c|c|c|}
\hline \multirow[b]{2}{*}{$\begin{array}{l}\text { Subject } \\
\text { No }\end{array}$} & \multicolumn{2}{|c|}{ Histamine study days } & \multicolumn{3}{|c|}{$A M P$ study days } & \multirow{2}{*}{$\begin{array}{l}\text { O } \\
N \\
\omega \\
\sigma\end{array}$} \\
\hline & Placebo & $\begin{array}{l}\text { Terfenadine } \\
180 \mathrm{mg}\end{array}$ & Placebo & $\begin{array}{l}\text { Terfenadine } \\
180 \mathrm{mg}\end{array}$ & $\begin{array}{l}\text { Terfenadine } \\
600 \mathrm{mg}\end{array}$ & \\
\hline $\begin{array}{l}1 \\
2 \\
3 \\
4 \\
5 \\
6 \\
7 \\
8 \\
9\end{array}$ & $\begin{array}{l}2 \cdot 7 \\
2 \cdot 9 \\
2 \cdot 2 \\
2 \cdot 2 \\
2 \cdot 1 \\
1 \cdot 0 \\
2 \cdot 2 \\
1 \cdot 5 \\
2 \cdot 0\end{array}$ & $\begin{array}{l}2 \cdot 6 \\
2 \cdot 7 \\
2 \cdot 1 \\
2 \cdot 8 \\
2 \cdot 8 \\
1 \cdot 2 \\
2 \cdot 5 \\
1 \cdot 4 \\
2 \cdot 3\end{array}$ & $\begin{array}{l}2 \cdot 6 \\
2 \cdot 7 \\
2 \cdot 2 \\
2 \cdot 3 \\
2 \cdot 0 \\
1 \cdot 3 \\
2 \cdot 4 \\
1 \cdot 4 \\
2 \cdot 0\end{array}$ & $\begin{array}{l}2 \cdot 8 \\
2 \cdot 6 \\
2 \cdot 3 \\
2 \cdot 9 \\
2 \cdot 7 \\
1 \cdot 2 \\
2 \cdot 8 \\
1 \cdot 4 \\
2 \cdot 2\end{array}$ & $\begin{array}{l}2 \cdot 6 \\
3 \cdot 0 \\
2 \cdot 3 \\
2 \cdot 7 \\
2 \cdot 9 \\
1 \cdot 3 \\
3 \cdot 0 \\
1 \cdot 3 \\
2 \cdot 0\end{array}$ & 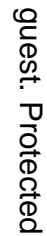 \\
\hline Mean & $2 \cdot 1(0 \cdot 2)$ & $2 \cdot 2(0 \cdot 2)$ & $2 \cdot 1(0 \cdot 1)$ & $2 \cdot 3(0 \cdot 1)$ & $2 \cdot 3(0 \cdot 2)$ & ర \\
\hline
\end{tabular}




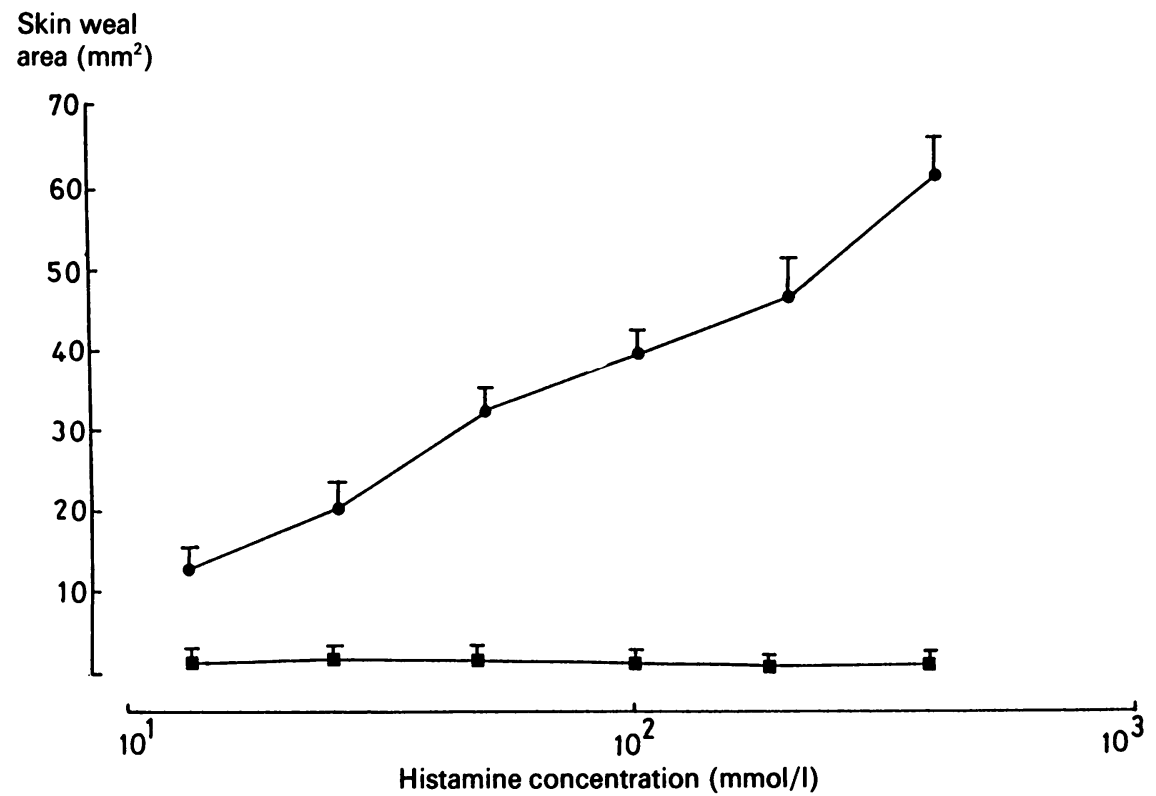

Fig 2 Effect of oral placebo (O) and terfenadine $180 \mathrm{mg}(\square)$ on the skin weal response to prick testing with histamine, 4-128 $\mathrm{mg} / \mathrm{ml}$ (13-416 mmol/l). Each point represents the mean and SEM for nine subjects.

ablated (fig $1 a$ ). This dose of terfenadine also inhibited the weal response to prick skin testing with histamine, causing a $97.9 \%(2 \cdot 1 \%)$ inhibition of the maximum histamine concentration used, $128 \mathrm{mg} / \mathrm{ml}$ (416 mmol/l) (fig 2).

The $\mathrm{PC}_{20}$ AMP caused a rapid decrease in $\mathrm{FEV}_{1}$ after placebo, reaching a mean maximum value of $72 \cdot 1 \%(3 \cdot 2 \%)$ of the postsaline baseline value at 6.6 $(1.8)$ minutes. The rate of recovery of FEV , was similar to that after histamine. After terfenadine $180 \mathrm{mg}$, FEV , fell to $88 \cdot 1 \%(2.5 \%)$ of the baseline value at $9 \cdot 8$ (3.7) minutes (fig $1 b$ ) and the bronchoconstrictor response to AMP measured as AUC was inhibited by $80.8 \%(18.0 \%)$ by comparison with that after placebo (p < 0.01). The AUCs following terfenadine $180 \mathrm{mg}$ for histamine and AMP provocation did not differ significantly.

Study 3

High dose terfenadine $(600 \mathrm{mg})$ inhibited the bronchoconstrictor response to AMP by $60.6 \%(18.7 \%)$ by comparison with the AUC after placebo ( $p<0.01$ ) and this did not differ significantly from the inhibition achieved by terfenadine $180 \mathrm{mg}(\mathrm{p}=0.5)$. At all times after five minutes from challenge, however, terfenadine $600 \mathrm{mg}$ afforded less protection than terfenadine $180 \mathrm{mg}$ (fig $1 b$ ). The mean time taken to achieve the maximum fall in FEV, with AMP increased from 6.6 (1.8) minutes after placebo to $9.8(3.7)$ minutes after terfenadine $180 \mathrm{mg}$ and $16.6(3.8)$ minutes after terfenadine $600 \mathrm{mg}$ ). The greater bronchoconstriction observed with the higher dose of the antihistamine was due to five subjects in whom terfenadine $600 \mathrm{mg}$ produced only $27 \cdot 4 \%(17 \cdot 4 \%)$ inhibition of the AUC, compared with $102.3 \%(23 \%)$ inhibition in the remaining four subjects.

Study 4

There was no shift in the methacholine concentrationresponse curves after terfenadine $180 \mathrm{mg}(\mathrm{p}=0.5)$. $\mathrm{PC}_{20}$ methacholine values ranged from 0.1 to $2.9 \mathrm{mg} /$ $\mathrm{ml}(0.3-14.7 \mathrm{mmol} / \mathrm{l})$ after placebo with a geometric mean of $0.4 \mathrm{mg} / \mathrm{ml}(2.1 \mathrm{mmol} / \mathrm{l})$ and from $0.1-3.0 \mathrm{mg} /$ $\mathrm{ml}(0.5-15.3 \mathrm{mmol} / \mathrm{l})$ after terfenadine $180 \mathrm{mg}$, with a geometric mean value of $0.4 \mathrm{mg} / \mathrm{ml}(2.1 \mathrm{mmol} / \mathrm{l})$ (table 4).

Table 4 Provocation concentrations of methacholine producing a $20 \%$ fall in $F E V_{1}\left(P C_{20}\right.$ from baseline $(\mathrm{mg} / \mathrm{ml})$

\begin{tabular}{lll}
\hline $\begin{array}{l}\text { Subject } \\
\text { No }\end{array}$ & Placebo & $\begin{array}{l}\text { Terfenadine } \\
180 \mathrm{mg}\end{array}$ \\
\hline 1 & $1 \cdot 6$ & $1 \cdot 1$ \\
2 & $2 \cdot 1$ & $3 \cdot 0$ \\
3 & $0 \cdot 2$ & $0 \cdot 2$ \\
4 & $0 \cdot 6$ & $0 \cdot 5$ \\
5 & $0 \cdot 4$ & $0 \cdot 4$ \\
6 & $0 \cdot 2$ & $0 \cdot 1$ \\
7 & $2 \cdot 9$ & $1 \cdot 7$ \\
8 & $0 \cdot 2$ & $0 \cdot 1$ \\
9 & $0 \cdot 1$ & $0 \cdot 1$ \\
Geometric mean & $0 \cdot 4$ & $0 \cdot 4$ \\
(range) & $(0 \cdot 1-2 \cdot 9)$ & $(0 \cdot 1-3 \cdot 0)$ \\
\hline
\end{tabular}




\section{Discussion}

This study shows that AMP administered by inhalation to patients with intrinsic (non-atopic) asthma causes bronchoconstriction with a time course similar to that observed with inhaled adenosine in subjects with atopic asthma. ${ }^{3}$ We have further shown that, in intrinsic asthma, bronchoconstriction provoked by AMP is inhibited to a major degree by the histamine $\mathrm{H}_{1}$ receptor anatagonist terfenadine. The inhibitory effect of this selective histamine $\mathrm{H}_{1}$ receptor antagonist suggests that release of histamine from activated mast cells in the bronchi has a central role in producing the constrictor airway effects of AMP and, by implication, adenosine, as previously suggested in atopic asthma. ${ }^{12}$

By constructing cumulative concentration-response curves for AMP and histamine and showing that these did not depart significantly from parallel, we were able to define the position of the curves as $\mathrm{PC}_{20}$ values and use these to derive an index of relative potency for the two bronchoconstrictor agonists. In the patients studied AMP was 8.4 times less potent than histamine, on a molar basis, in causing bronchoconstriction, compared with a fourfold difference in potency when the same comparison was made between these two agonists in a group of atopic asthmatic subjects. ${ }^{6}$ In a previous study no difference in responsiveness to adenosine between atopic and non-atopic asthmatic subjects was found. ${ }^{18}$

In this group of non-atopic asthmatic subjects terfenadine $180 \mathrm{mg}$ produced a significant degree of bronchodilatation, similar to that seen in atopic asthma; ${ }^{19}$ but it failed to protect the airways against the bronchoconstrictor effect of methacholine. This suggests that in both forms of the disease the airways are under some degree of histamine tone.

After terfenadine $180 \mathrm{mg}$ the bronchoconstrictor response to inhaled AMP was greatly attenuated. The same dose of terfenadine completely inhibited both the bronchoconstrictor response to a dose of inhaled histamine sufficient to cause a mean maximum fall in FEV , to $69.7 \%$ of baseline, and the skin weal response to histamine $128 \mathrm{mg} / \mathrm{ml}(416 \mathrm{mmol} / \mathrm{l}$-figure 2$)$. The specificity of this dose of terfenadine in producing $\mathrm{H}_{1}$ histamine receptor blockade is supported in these non-atopic subjects by its failure to protect against bronchoconstriction induced by methacholine. These findings are in agreement with those of two previous studies, which showed a 35 fold protection of the airways against the bronchoconstrictor action of inhaled histamine but no protection against methacholine. ${ }^{1920}$ We propose therefore that the attenuation of AMP provoked bronchoconstriction by terfenadine is due to its action as an antagonist of $\mathbf{H}_{1}$ histamine receptors and argue for a central role of histamine release in the airways response to this inhaled purine derivative in individuals with non-atopic asthma. These results are in agreement with those of a previ@us study, in which terfenadine and chemically unrela $\overline{\bar{c}} d$ and potent $H_{1}$ histamine receptor antagon astemizole, inhibited the bronchoconstrictor response to AMP in subjects with atopic asthma; ${ }^{12}$ but they would appear to contradict the findings of another study, which showed no significant increase in plasma concentrations of histamine or neutrophil chemotaenic factor after AMP challenge. ${ }^{10}$ These latter findi葬s may have been due to lack of sensitivity of the histamine assay or to the selection of subjects with such a high degree of non-specific bronchial reactivity that very little histamine release would be needod before bronchoconstriction occurred.

Histamine is the only known preformed spa smogenic mediator present in the secretory granules $\rightarrow f$ human lung mast cells, so the inhibitory effect of histamine $H_{1}$ receptor antagonists on the airwa response to AMP indicates that this nucleotide (andक्षy implication adenosine) causes bronchoconstriction $\$$ y potentiating ongoing mediator release from activated mast cells in the bronchial mucosa. In atopic asthma the number of mast cells recovered by bronchoalveolar lavage is increased, and their spontaneous release of histamine is greater than from mast cells recovered from normal lung. ${ }^{21}$ The ability of AMPhito provoke an antihistamine sensitive bronchoconst $\frac{0}{\mathrm{nc}}$ tion in intrinsic asthma suggests that these cells $\frac{a r e}{2 r}$ already activated in the airways-although, previously discussed, the level of mast cell activationin the two disease forms may differ. Recently Marquazdt et al have reported that adenosine and related sypthetic analogues potentiate degranulation of muri he interleukin-3 dependent, bone marrow derived mist cells when stimulated for mediator release with the calcium ionophore A23187 or antigen, ${ }^{11}$ but do 짜 affect the release of newly generated mediators. Sogine support for a similar mechanism operating for human lung mast cells is provided by the observation that adenosine and its non-hydrolysable analogues haveno effect as secretagogues of lung mast cells per se, but are able to potentiate ongoing IgE dependent histaminge release. $^{8}$

In the patients with intrinsic asthma we studied, terfenadine $180 \mathrm{mg}$ inhibited the airways reponse inhaled AMP by $80.8 \%$-compared with $86.6 \%$ when the same dose of terfenadine was studied in atopic asthmatic subjects. ${ }^{12}$ Since terfenadine and f్fts metabolites are competitive antagonists for histampe at its $H_{1}$ receptors, it is possible that the reduction in FEV , with AMP challenge that remained after treântment with terfenadine $180 \mathrm{mg}$ was due to incomplote antagonism of endogenously released histamine. further inhibitory activity against inhaled AMP, however, was observed after we increased the dose of 
terfenadine to $600 \mathrm{mg}$, suggesting that the terfenadine resistant response represents a non-histamine component. The mean time to maximum bronchoconstriction with AMP was delayed from 3.7 minutes after placebo to 16.6 minutes after the higher dose of terfenadine, suggesting that inhaled AMP might also enhance the release of newly formed bronchoconstrictor mediators such as prostaglandin $D_{2}$ and leukotriene $\mathrm{C}_{4}$, since their release from activated mast cells is delayed beyond that of histamine. ${ }^{22} 23$

The higher dose of terfenadine resulted in less inhibition of the bronchoconstrictor response to inhaled AMP (60.6\%) than did terfenadine $180 \mathrm{mg}$ $(80 \cdot 8 \%)$, although this difference was not significant. It is difficult to account for this observation. Compliance is unlikely to have been a problem since the two subjects with the greatest bronchoconstrictor response after terfenadine $600 \mathrm{mg}$ showed complete inhibition of the skin weal response to prick testing with histamine at a concentration of $416 \mathrm{mmol} / \mathrm{l}$.

In conclusion, the data presented here are consistent with the suggestion that most of the bronchoconstrictor response to inhalation of AMP in non-atopic asthmatic subjects is due to histamine release in the airways. We suggest that adenosine and its nucleotide AMP cause bronchoconstriction in these non-atopic subjects by potentiating ongoing release of preformed mediators from activated airway mast cells. Our data would also be consistent with an additional effect of these purine derivatives, possibly augmentation of the release of newly generated mediators, either from mast cells or from other mediator secreting cells in the airways.

We thank Mrs M Dowling for typing the manuscript.

\section{References}

1 Fain JN, Malbon CC. Regulation of adenylate cyclase by adenosine. Mol Cell Biochem 1979;25:143-69.

2 Wolff J, Londos C, Cooper DMR. Adenosine receptors and the regulation of adenylate cyclase. Adv Cyclic Nucleotide Res 1981;14:199-214.

3 Mann JS, Holgate ST, Renwick AG, Cushley MJ. Airways effects of purine nucleosides and nucleotides with bronchial provocation in asthma. J Appl Physiol 1986;61:1667-76.

4 Cushley MJ, Tattersfield AE, Holgate ST. Adenosine antagonism as an alternative mechanism of action of methylxanthines in asthma. Agents Actions 1983; 13 suppl:109-31.

5 Cushley MJ, Tattersfield AE, Holgate ST. Adenosineinduced bronchoconstriction in asthma: Antagonism by inhaled theophylline. Am Rev Respir Dis 1984;129:380-4.

6 Mann JS, Holgate ST. Specific antagonism of adenosineinduced bronchoconstriction in asthma by oral theophylline. Br J Clin Pharmacol 1985;19:685-92.
7 Cushley MJ, Tallant N, Holgate ST. The effect of single dose intravenous dipyridamole on histamine- and adenosine-induced bronchoconstriction in normal and asthmatic subjects. Eur J Respir Dis 1986;86:185-92.

8 Hughes PJ, Holgate ST, Church MK. Adenosine inhibits and potentiates IgE-dependent histamine release from human lung mast cells by an $\mathbf{A}_{2}$-purinoceptor mediated mechanism. Biochem Pharmacol 1984;33:3847-52.

9 Church MK, Holgate ST, Hughes RJ. Adenosine inhibits and potentiates IgE-dependent histamine release from human basophils by an $\mathrm{A}_{2}$-receptor mediated mechanism. Br J Pharmacol 1983;84:719-26.

10 Cushley MJ, Holgate ST. Adenosine-linked bronchoconstriction in asthma: role of mast cell mediator release. J Allergy Clin Immunol 1985;75:272-8.

11 Marquardt DL, Walker LL, Wasserman SJ. Adenosine receptors on mouse bone-marrow derived mast cells. Functional significance and regulation by aminophylline. J Immunol 1984;133:932-7.

12 Rafferty P, Beasley R, Holgate ST. The contribution of histamine to immediate bronchoconstriction provoked by inhaled allergen and adenosine 5 '-monophosphate in atopic asthma. Am Rev Respir Dis 1987;136:369-73.

13 Rackemann FM. A working classification of asthma. Am J Med 1937;3:601-6.

14 Lewis RA. Therapeutic aerosols. In: Cumming G, Bonsignore $\mathrm{C}$, eds. Drugs and the lung. London: Plenum Publishing Company, 1984:63-86.

15 Chai H, Farr RS, Froehlich LA, et al. Standardization of bronchial inhalation challenge procedures. J Allergy Clin Immunol 1975;56:323-7.

16 Hovell CJ, Beasley CRW, Mani R, Holgate ST. Laser doppler flowmetry for determining changes in cutaneous blood flow following intradermal injection of histamine. Clin Allergy 1987;17:469-79.

17 Chung KF, Morgan B, Keyes SJ, Snashall PD. Histamine dose-response relationships in normal and asthmatic subjects: the importance of starting airway calibre. $\mathrm{Am}$ Rev Respir Dis 1982;126:849-54.

18 Cushley MJ, Tattersfield AE, Holgate ST. Inhaled adenosine and guanosine on airway resistance in normal and asthmatic subjects. Br J Clin Pharmacol 1983;15:161-5.

19 Rafferty P, Holgate ST. Terfenadine as a potent and specific $\mathrm{H}_{1}$-histamine receptor antagonist on asthmatic airways. Am Rev Respir Dis 1987;135:181-4.

20 Patel KR. Effect of terfenadine on methacholine-induced bronchoconstriction in asthma. J Allergy Clin Immunol 1987;79:355-8.

21 Flint KC, Leung KBP, Hudspith BN, Brostoff J, Pearce FL, Johnson JMcI. Bronchoalveolar mast cells in extrinsic asthma: a mechanism for the initiation of antigen-specific bronchoconstriction. Br Med J 1985; 291:923-6.

22 Holgate ST, Burns GB, Robinson C, Church MK. Anaphylactic and calcium-dependent generation of prostaglandin $\mathrm{D}_{2}\left(\mathrm{PGD}_{2}\right)$, thromboxane $\mathrm{B}_{2}$ and other cyclooxygenase products of arachidonic acid by dispersed human lung cells and relationship to histamine release. J Immunol 1984;133:2138-44.

23 MacGlashan DW, Schleimer RP, Peters SP, et al. Generation of leukotrienes by purified human lung mast cells. J Clin Invest 1982;70:747-51. 